DOI https://doi.org/10.30525/978-9934-26-004-9-21

\title{
ФЕНОМЕН ЦІННІСНОГО КОНЦЕПТУ «ЛЮБОВ» \\ В УКРАЇНСЬКОМУ СВІТОГЛЯДІ НА ЗРАЗКАХ НАРОДНОЇ ПІСЕННОЇ ТВОРЧОСТІ ПОДІЛЛЯ
}

\author{
Бегас Н. О. \\ студентка II курсу магістратури філологічного факультету \\ Донецького національного університету імені Василя Стуса \\ м. Вінниця, Украӥна
}

Основу кожної культури становить відповідна система цінностей. Національні цінності $€$ основними чинниками, що визначають пріоритети духовного життя народу, забезпечують цілісність концептосфери етнічної спільноти, збереження культурних надбань попередніх поколінь і виживання етносу як носія унікальної культури в умовах глобалізації [1, с. 26].

3 давніх віків наша українська земля славиться сприятливими кліматичними умовами, географічним розташуванням та багатою історією. Зазирнути лише варто у добу Трипілля: розмальовка глиняного посуду, вперше у світі винайдення колеса, пошиття одягу. Якщо брати до уваги такі цінності, як доброта, щедрість, чесність, справедливість, любов до родини, до землі, повага до жінки, то в нашого українського народу вони були домінуючими, і оспівуються у народних піснях, які сформовані віками.

Ключовими серед них є такі: «любов», «милосердя», «чемність» i «ввічливість», шанування батьків», «родинні стосунки», «рід», «любов до рідної землі», «праця», «волелюбність» та ін.

Розкриваючи сутність ціннісних концептів українського народу, концепту «любов» у фольклорі Поділля, слід виділити мету наших тез дослідження, пошуки, фіксація давніх автентичних народних пісень, їх реконструкція, обробки; виявлення ціннісних концептів серед джерел фольклору та пристосування їх до сучасності; об'єктом дослідження $\epsilon$ фольклор Подільського краю, зібраний особисто автором під час польових етнографічних експедицій, який є невід'ємною складовою української духовної культури в контексті багатовікового культурноісторичного процесу і в культурному просторі XXI століття.

Концепт «любов» в українській мові має унікальне бінарне втілення любов/кохання, де друге поняття передає сферу природних глибоких 
інтимних переживань і має більш насичену семантику та словотвірний ряд: кохати, кохатися, коханий, кохана, коханець, коханка, закоханий та ін. Любов слугує позначенням широкого кола глибокої прихильності людини до когось або чогось, а кохання- переважно тільки до особи іншої статі: «котилися вози з гори та в долині стали, любилися, кохалися, тепер перестали»; «ой, знаю, кого кохаю, тільки не знаю, з ким жити маю»; «ой, чи всі тії вінчаються, щяо любляться та кохаються?».

Слово любов слугує позначенням широкого кола глибокої прихильності людини до когось або чогось, а кохання - переважно тільки до особи іншої статі: «ой, знаю, кого кохаю, тільки не знаю, з ким жити маю». Разом з тим, у фольклорних творах нерідко обидва ці синоніми використовуються в одному контексті, що, напевне, сприяє вербалізації вищого рівня емоційності: «котилися вози з гори та в долині стали, любилися, кохалися, тепер перестали»; «ой, чи всі тії вінчаються, що любляться та кохаються?» [2, с. 108].

Для українського фольклору притаманні фітоморфні, орнітоморфні образи закоханих, витоки яких сягають ще в міфологічну картину світу 3 притаманним їй синкретизмом, анімістичними й тотемістичними віруваннями, вірою в магічний зв'язок із природними явищами [3].

Однією поширених пісень про кохання, яку нам вдалось зафіксувати у кількох районах Вінниччини $\epsilon$ пісня: «Ой там на горі», в якій яскраво змальовують образи двох закоханих, з орнітоморфним образом: «пара голубів», де «голубка» - дівчина, «голуб» - хлопець, а «стрілець» - їх розлучник, який може характеризувати образ минулих подій, при яких молоді пара не змогла надалі бути разом: війна, відстоювання та захист своєї батьківщини.

Перетворення людей на птахів в українському фольклорному дискурсі цілком характерне і простежується у багатьох народних піснях різних жанрів. До прикладу:

«Коло млину, коло броду два голуби пили воду.

Вони пили воркутіли, ізнялися полетіли ...» [4].

У народній уяві голуб - свята, «божа пташка» (як ластівка, жайворонок, соловей), символ чистоти, очищення та весільноритуальних обрядів. Любовно-шлюбна символіка голуба представлена у повір'ях, магії, весільних обрядах і піснях. Фігурками голуба прикрашали коровай. Голуб з голубкою, що воркочуть, - символ закоханих. Два голуби - символ любові, творчості. Тому перевтілення людських образів молодих закоханих на голубів $є$ характерним у фольклорному дискурсі:

Ой, ти дубе, дубе, дубе зелененький 
Ой на тобі, дубе, два голуби гуде.

Два голуби гуде й голубка туркоче

Любив козак дівчину,

Та й кидати не хоче [5, с. 291].

Показово, що концепт «Любов» в українському фольклорі досить часто вербалізується опосередковано: через монологи й діалоги закоханих, насичених ніжно-пестливими зверненнями, навіть тоді, коли зміст пісні трагічний і пов'язаний із раннім шлюбом або нещасливим заміжжям: «дівчинонька», «лебедонька» 3 епітетами: «як маківка процвітала», «рідна ненька», тощо.

«...дівчинонька плаче, сльози проливає,

Свою долю проклинає.

Ой якби я була знала,

Та не йшла заміж, а гуляла.

У рідного батька, у рідної неньки

Як маківка проивітала» [6].

В особливо трагічних моментах у піснях про кохання простежується концепт поваги один до одного, що характерно для відносин української молоді. Цей концепт ми відслідковуємо у ніжних зверненнях один до одного навіть під час розлуки: «милий», «милая»:

«Покидаєи, мене милий

Покидаєи, покидай.

А щзо було поміж нами

Нікому не повідай» [7].

Пестливі епітети звернень один до одного крізь призму концепту «любов» простежуються, як під час трагічного, та і щасливого кохання: «гарна чорнобривка», «серденьком назвала», «козаченько».

«...мусів шапку зняти,

Добрий день сказати,

Вона стала, відказала,

Серденьком назвала...» [7].

Опис природи простежується майже у всіх видах пісень про кохання, адже місце і час зустрічі для молоді це вечірній час, коли навколо спокій, важкий робочий день позаду, і закоханих поєднує лише безмежний простір зоряного неба, тихий, теплий вечір. Емоційно насичені образи, мальовничі картини природи, в яких вербалізуються ціннісні концепти, відображають поетичне світосприймання українців Поділля й українського етносу загалом: «Й у полю береза, ци у полю кудрява», «Не та роза, що за садом, а та роза, щэо в саду», «Якби мені не тиночки, та й не перелази», тощо.

Серед ціннісного концепту «любов» слід виділити не лише ліричну, інтимну, чуттєві сторони, а й також повчальну, виховну функцію, як 
один із елементів вірності у коханні, що $є$ важливою людською цінністю у будь-які історичні віхи. Мотив вірності, в якому знайшли своє відображення морально-етичні принципи українського народу, його погляди на щасливе кохання: «а ще гірше тому, хто дві-три кохає», «не той милий, щьо двох любить, а той милий, щьо одну» [6], [7]. Часто у пісня про кохання проявляється баладна традиція, де йдеться про чарування чи ворожбу: «В саду ходила, ивіти збирала, кого любила - причарувала» [6].

Вони часто наповнені незвичайними, небуденними ситуаціями (вдова приворожує молодого хлопця, дівчина - чужого нареченого і т. п.).

Дозволь, мати, вдову взяти.

Вдова вміє чарувати.

Вдова буде шанувати.

Вчарувала мужа свого,

Не дозволю вдову взяти

Вчарує й тя молодого [5].

Ціннісні концепти родинного побуту у піснях про кохання відображаються у життєвих явищах гумористичного стилю. На них позначилась весела вдача українців, які вміють із гумором сприймати несподівані повороти долі, знаходити розраду у влучному жарті. Саме через гумор простежується виховна та повчальна функції, де згадується залицяння хлопця до дівчини, висміюються залицяльники-невдахи, які не вміють заговорити до дівчини, або бояться її батьків:

«...я хлопецьь молодий - в свого батька вдався.

Фітю-мітю, поза плітю в коноплі сховався...» [6]

Часто образи закоханих оспівуються не лише серед молоді, але i серед людей похилого віку. Здавалося б, гумористичний зміст створений для сміху, проте у ньому закладена також життєво-важлива функція, які відобажає ціннісний концепт поваги один до одного на схилі літ:

«В місяиі іюлі випала пороша,

А дід бабу полюбив, бо баба хороша.

І без зуба, і без ока, без ноги одної,

А він горнеться до неї, як до молодої» [7].

Слід сказати, що концепт «любов» в українських народних піснях має унікальне значення в житті людини, де реальне відступає на другий план (так, ніби його і не існує), у них, як правило, не згадуються побутові реалії (предмети щоденного вжитку, елементи домашньої праці).

Серед дослідженого жанру пісень про кохання можна виділити головні функції: емоційно-чуттєву, повчальну, виховну, інтимноліричну, які крізь призму фольклорного дискурсу зберігають найважливіші людські цінності такі як: вірність, створення майбутньої сім'ї, повага до родинних звичаїв та традицій. 


\title{
Література:
}

1. Бегас Н. Репрезентація ціннісних концептів українського етносу у фольклорі Поділля. Креативність як феномен людського буття в культурі: матеріали VIII всеукраїнської науково-практичної конференції студентів та молодих науковців (Вінниця, 14 травня 2020 р). Вінниця, 2020. C. 26.

2. Манакін В. М. Мова і міжкультурна комунікація : навчальний посібник. К. : ВЦ «Академія», 2012. 288 с.

3. Лановик, Мар'яна Богданівна. Українська усна народна творчість : підручник / М. Б. Лановик, 3. Б. Лановик. - 3-тє вид., стер. . - Київ: Знання-Прес, 2005. - 591 с.

4. Свідчення та запис автора Бегас Н.О., від Коваля Олександра Івановича, 29.05.1960 р.н., с. Яришів, Могилів-Подільського р-н.

5. Пісні Поділля. Записи А. Присяжнюк в с. Погребище. 1020-1970. Наукова думка. К. -1976 р. 520 с.

6. Свідчення та запис автора Бегас Н.О., від Колісніченка Володимира Семеновича, 22.09.1932 р.н., с. Маянів, Вінницької області, Тиврівського району.

7. Народні пісні, досліджені автором в с. Шершні, Тиврівського р-н, Вінницької обл. https://www.youtube.com/watch? $=2 \mathrm{~h} 1$ Mgreri80\&t=3s

DOI https://doi.org/10.30525/978-9934-26-004-9-22

\section{СТОРІНКИ ІСТОРІї ХАРКІВСЬКОЇ МУЗИЧНО-ТЕОРЕТИЧНОЇ ШКОЛИ}

\author{
Борисенко М. Ю. \\ кандидат мистеитвознавства, доиент, \\ дочент кафедри теорії музики \\ Харківського національного університету мистецтв \\ імені І. П. Котляревського \\ м. Харків, Україна
}

Розвиток музично-теоретичної школи у Харкові тісно пов'язаний із становленням професійної музичної освіти в Україні, виникненням музичних товариств, навколо яких формувалася та консолідувалася музична спільнота.

Активне поширення концертної діяльності на теренах країни, у великих українських містах стимулювало не тільки існуючу на той час 